\title{
Thoughts on information and integration in honey bee colonies
}

\author{
Thomas D. Seeley \\ Section of Neurobiology and Behavior, Cornell University, Ithaca, NY 14853, USA
}

(Received 6 June 1997; accepted 27 October 1997)

\begin{abstract}
Solving the puzzle of colony integration in honey bees requires understanding how a worker bee acquires the information that she needs to decide correctly, moment-by-moment, what task to perform and how to perform it. To help us understand how the bees inside a beehive acquire this information, I share some thoughts about information flow within honey bee colonies. These thoughts are based on recent findings about how a colony works as a unified whole in gathering its food. (1nra/DIB/AGIB/Elsevier, Paris
\end{abstract}

Apis mellifera / communication / honey bee / information / social behavior

\section{INTRODUCTION}

Of all the mysteries embodied in a honey bee colony, perhaps the greatest is how thousands of bees can work together with such coherence that a colony functions as a single, smoothly running, individually purposeful entity. The mystery of colony integration has intrigued humans for hundreds of years and, little by little, much has been revealed from the treasure chest of the bee hive. The ability of a colony to control its nest temperature, to choose a home site, and to distribute its foragers among flower patches - these are some of the puzzles whose solutions have gradually emerged from scientific studies. But many other aspects of the unity of colonies remain enigmatic and so draw us onward.

In this article, I hope to advance our understanding of the functional integration of honey bee colonies by sharing some thoughts that have emerged from analyzing how a colony gathers its food [reviewed in Seeley (1995)]. These thoughts all concern the information used by worker bees as each one decides,

* Correspondence and reprints

Tel.: (1) 607539 7897; fax: (1) 607 254-4308; e-mail: tds5@ cornell.edu 
moment-by-moment, how she should behave to contribute to the common good. (In this article, the word 'information' denotes simply knowledge obtained by a bee from its environment; it does not denote a quantitative measure of the reduction of uncertainty about conditions, as in formal information theory.) The close connection between information and integration is made clear by noting that the general problem of colony integration can be framed in terms of two more specific problems: 1) maintaining a proper distribution of individuals among the various tasks performed within a colony, and 2) achieving coordination among the individuals working on each task. These can be thought of as the problems of betweentask and within-task coordination. From the perspective of the individual bee, the first problem is one of knowing what to do, while the second is one of knowing how to do it. Because the solutions to these problems depend critically upon workers possessing adequate information to decide correctly what to do and how to do it, it is clear that much of the challenge of understanding colony integration lies in analyzing the acquisition and processing of information by the workers in a colony.

\section{SIGNAL INFORMATION VERSUS CONTEXTUAL INFORMATION}

Within a honey bee colony, there is extensive overlap of the reproductive interests of individuals, hence it is not surprising that bees have evolved many special means for sharing information, i.e. for communicating. Following Lloyd (1983), I will use the term 'signal' to denote any structure or behavior that has been molded by natural selection for the purpose of conveying information. (Note: the term 'signal', as used here, is synonymous with the classical ethological term 'sign stimulus'.) The signals that have evolved in honey bees are primarily chemical and mechanical stimuli, since they must be easily perceived by bees in the darkness that prevails inside the hive. Table I lists the known signals of honey bees. We can see that in each case a signal is a means whereby one bee can convey to her nestmates information that helps them decide what to do next (e.g. attack an intruder, forage for pollen, or feed a nestmate) and how to do it (e.g. sting the intruder here, obtain pollen from flowers just outside the hive, or give me just a little food).

Because signals are specialized to be informative, they are likely to be unusually pertinent among the other sources of information with which they occur. However, it should be recognized that a worker bee receiving a signal has access to and can process much information besides what she obtains from the signal. Each time she perceives a particular signal she may also register information regarding her particular 'location' in the nest (e.g. dance floor, brood nest, honey combs), her particular 'time' (e.g. time of day, season of the year), her particular 'behavioral context' (e.g. defending the nest, tending brood, resting), and her particular 'social identity' (e.g. age, experience, physiological state). I would like to suggest that the information processed by a bee in conjunction with receiving a signal - which $\mathrm{I}$ will call 'contextual information' - is often extremely rich, for in principle it comprises anything that a bee can recall or perceive at the time. And I wish to stress that to focus only on signals as sources of information for bees would be folly, for to do so would blind one to all but a small part of the total body of information used by bees as they make behavioral decisions.

Although we do not know the full scope of information acquisition and integration by worker bees in even one behavioral context, it is clear that sophisticated information processing by a worker bee receiving a signal is not just a possibility, but a 
Table I. Stimuli recognized as signals in honey bee colonies.

Stimulus Function $\quad$ Reference

Worker-produced chemical signals

Nasonov gland pheromone

Footprint pheromone

Sting gland pheromone

Mandibular gland pheromone

Brood pheromone

Queen-produced chemical signals

Mandibular gland pheromone

Dufour gland pheromone

Tergal gland pheromone

Footprint pheromone attraction of nestmates

orientation of nestmates

elicitation of aggression

elicitation of aggression

recognition of brood
Winston (1987)

Winston (1987)

Winston (1987)

Winston (1987)

Koeniger and Veith (1983)

Worker-produced mechanical signals

Waggle dance

Tremble dance

Shaking signal (DVAV)

Buzz run

Grooming invitation

Worker piping

Antennation recruitment to food sources and nestsites

activation of receiver bees

activation of workers

indication of departure

invitation of grooming

unknown

solicitation of food

or attention
Winston and Slessor

(1992)

Ratnieks (1995)

Renner and Vierling (1977)

Lensky and Slabezki (1981)

Queen-produced mechanical signals

Queen piping

indication of queen's

presence

von Frisch (1967),

Sandeman et al. (1996)

Seeley (1992)

Schneider et al. (1986)

von Frisch (1967)

Milum (1947)

Pratt et al. (1996)

Park (1925)

Simpson and Cherry

(1969)

reality. Consider, for example, the case of bees standing on the combs just inside the hive entrance during a period of good weather when the colony's foragers are busily bringing home load upon load of nectar, pollen and water. These bees are surrounded by foragers excitedly advertising with waggle dances the various sources of their foraging success. If one watches several of the unemployed bees, individually, for several minutes each, one will see various responses to the dance signals produced by the successful foragers. Some bees will press in closely behind a dancing bee, then follow her throughout several circuits of her dance, and finally turn away and scurry out the hive entrance. Others will start to follow a dancing bee closely, seemingly with great interest, but after a few seconds they will leave the dancer and crawl away. Still others will completely ignore the dancing 
bees, and instead will seek to unload nectar or water from the incoming foragers. These different responses to the waggle dance signal reflect differences in the contextual information possessed by the various bees on the dance floor (Seeley and Towne, 1992). The bees that follow a dancer closely and extensively are most probably bees that possess prior foraging experience, but have abandoned their old food source and so seek a new one. The bees that follow a dancer only briefly are probably also experienced foragers, but ones that have not yet abandoned their prior food source. Their behavior suggests that they are seeking news of the renewal of their previous day's food source, hence when each of these bees realizes that the dancing bee is advertising a different source, she turns away as if quickly realizing, 'she is not advertising my flower patch'. Finally, the bees that ignore the foragers' dances and instead relieve them of their loads are bees that have not yet begun foraging and instead are functioning as receiver bees (Seeley, 1989). These three types of bees perceive different sets of contextual information when encountering the waggle dance signal, consequently they show three kinds of response to this one type of signal.

It is likely that what I have written so far scarcely begins to express the complexity of the information acquisition and processing that is performed by a worker bee, whose sensory system is acute, hive environment is variable, and behavior is flexible. So let us consider further this same example, focusing on the bees that extensively follow a dancing bee and are aroused to leave the hive. A closer analysis of the response of these bees to the dance signal may reveal large changes in relation to contextual information about the colony's forage needs. Specifically, these bees may selectively follow dances advertising either nectar sources, pollen sources, or water sources, depending on their colony's need for energy, protein or water. Such sophistication by the dance followers could be important as one of the mechanisms underlying the ability of a colony to keep its foragers distributed among the tasks of nectar collection, pollen collection and water collection in accordance with its forage needs [discussed further in Seeley (1995)]. Likewise, an analysis of the response of worker bees to the queen bee's mandibular pheromone signal may reveal dramatic changes in behavior in relation to changes in contextual information about the colony's state and time of year. For example, most of the time workers respond to this signal by refraining from rearing additional queens, but under the influence of a certain set of inputs of contextual information (certain time of the year? certain abundance of brood? certain level of crowding in the hive?) the workers may alter their response and begin rearing queens in preparation for swarming. The workers may receive at all times the chemical signal indicating that their queen is alive and well, but in one context they may decide it is best to not rear queens while in a different context they may decide that rearing queens is the best course of action.

The general message here is that as we seek to understand how individual workers decide how to behave to foster colony functioning, we are right to place special emphasis on the analysis of signals, because many of them have evolved specifically for spreading information about a colony's labor needs. But at the same time, we must not overlook the fact that when a worker bee processes the information in a signal, she often integrates the signal information with a large amount of contextual information. And as the above discussion attempts to show, this contextual information can strongly influence a worker's response to a signal. Indeed, a worker may even choose to 
ignore a signal in light of certain contextual information. Hence it seems likely that a full understanding of the way that any particular signal contributes to the smooth functioning of a honey bee colony will also require a careful analysis of the contextual information used by the workers in association with this signal.

\section{A MULTITUDE OF CUES}

In the preceding section I have argued that much of the information with which worker bees make behavioral decisions comes from sources other than specially evolved signals. I have not, however, discussed explicitly what these alternative sources of information are. In principle, they are anything that a worker bee can perceive. Following Lloyd (1983), I will use the term 'cue' to denote any informative variable perceived by a bee that has not been shaped by natural selection specifically to convey information, but that instead conveys information incidentally. Cues and signals are, therefore, logically distinct categories of informationbearing variables. What, then, is the relationship between cues and contextual information? The two terms are not synonymous. Although cues are the source of most contextual information, there are many cues used by worker bees not in association with a communication signal. Hence, we must view cues more broadly than just as sources of contextual information. Consider, for example, the level of atmospheric carbon dioxide in a bee hive. This is an important cue for worker bees, one that indicates the need for hive ventilation (Seeley, 1974), but there is no evidence that it influences how bees respond to any communication signal. Therefore it is a cue, but apparently it is not a source of contextual information. In short, most if not all sources of contextual information are cues, but not all cues are sources of contextual information.
In table II, I have assembled a list of known or suspected cues used by honey bees. This list of cues is long, approximately twice as long as the list of signals in table $I$. I hasten to add, however, that sometimes it is not clear whether an item should be categorized as a signal or as a cue, so some of the things listed as cues may prove to be signals (and a few of the items listed as signals in table I may prove to be cues). For instance, I have placed the odor of dead bees in the cue category, since it is likely that this odor is an incidental by-product of the decomposition of a dead bee, but it may turn out that bees possess exocrine glands whose secretions are released upon death to provide a conspicuous marker of a dead bee. If so, then the odor of dead bees would be a signal, not a cue. Conversely, 1 have placed the brood pheromone in the signal category, since it is likely that the immature bees have evolved a special signal of their presence, but it may be that this pheromone is simply an automatic by-product of the biochemical processes underlying the growth and maturation of bees. If so, then the brood pheromone would be a cue, not a signal. Much of the ambiguity about cues versus signals reflects the fact that many signals have evolved from cues and have retained their original information content even though they have been molded by natural selection to express this information more strongly and precisely than was originally the case. Of course, there are also many cues and signals whose status is not ambiguous. Nest temperature, ragged cell cappings and unpacked pollen loads are all certainly cues, whereas the waggle dance, tremble dance and Nasonov gland pheromone are all undoubtedly signals.

Although it is not always clear whether a particular source of information inside a bee hive is a signal or a cue, I believe that the numerical predominance of cues over signals, suggested by the relative lengths of tables $I$ and $I I$, will prove correct. In 
Table II. Stimuli recognized or suspected as cues in honey bee colonies.

Stimulus Use Reference

Chemical cues

Floral odor on waggle dancer

Colony odor

Carbon dioxide level in

hive atmosphere

Dead bee odor

Empty comb odor

Dead or diseased brood odor

Pollen odor on waggle dancer

Propolis odor on waggle

dancer

Odor of cell contents

Dry or hungry brood

Tactile cues

Cell wall thickness

Cell size (worker or drone)

Partially capped cell

Incomplete cell

Ragged cell cappings

Unpacked pollen loads

in cell

Debris inside the hive

Debris on self

Bare nest-cavity walls

Drafts of cold air

Congestion of nestmates

Vibration of nest

Number of unloading

rejections by receiver bees

Abundance of drone cells

Orientation of larvae in cells

Time cues

Time spent searching for a nectar receiver bee

Time spent searching for

a water receiver bee

Time spent searching to find a cell for nectar storage

Time spent searching for

a nectar forager

Time spent searching for a cell containing pollen

Visual cues

Light coming in the entrance opening

Temperature cues

Temperature inside the hive indication of flower type

recognition of nestmates

indication of ventilation need

von Frisch (1967)

Breed (1985)

Seeley (1974)

recognition of dead bee

indication of empty comb

Visscher (1983)

recognition of dead or diseased brood None

recognition of dancer bearing pollen None

recognition of dancer bearing propolis None

indication of brood or food,

None

or of empty cell needing cleaning

indication of brood needing to be fed None

indication of need for cell wall

planing

recognition of cell type

indication of need for cell capping

indication of need for cell building

indication of need for trimming

cell cappings

indication of need for packing

pollen

indication of need to remove debris

indication of need for grooming

indication of need to propolize

cavity walls

indication of cracks needing

to be sealed with propolis

indication of colony strength

indication of disturbance by predator

indication of colony's need for

more water

indication of colony's need for

more drone cells

indication of where to place food

in cell

Martin and Lindauer

(1966)

Koeniger (1970)

Lindauer (1952)

Darchen (1968)

None

Parker (1926)

None

None

Seeley and Morse

(1976)

Seeley and Morse

(1978)

Simpson (1973)

Kühnholz and Seeley

(1997)

Free (1967)

Winston (1987)

indication of colony's need for higher nectar influx

indication of colony's need for

higher water influx

indication of colony's need for

more storage comb

indication of colony's need for

nectar receivers

indication of colony'spollen

reserve

Seeley and Tovey

(1994)

Kühnholz and Seeley

(1997)

Pratt, submitted

None

None

indication of the exit direction

Hess (1916)

indication of need for heating or cooling the nest
Heran (1952) 
other words, I believe that a large majority of the information sources used by bees to decide what to do (and how to do it) will be cues rather than signals. My belief is based on two insights. The first is that pathways of information flow will evolve more readily when they involve cues rather than signals. The evolution of cuing involves only the formation of an adaptive response to a pre-existing stimulus (the cue), whereas the evolution of signaling involves the adaptive modification of both a stimulus (the signal) and a response. All else being equal, then, we should expect more forms of cuing than of signaling in colonies. The second insight is that the process of colony integration is largely a matter of information flow from colony to individual, so that each individual can adjust its behavior in accordance with the activities of the other colony members. It seems likely that this colony-to-individual information flow will occur mainly via cues because any grouplevel indicator which individuals monitor for co-ordinating their actions is likely to be a by-product of the combined activities of a group (a cue) rather than a grouplevel phenomenon that has evolved specifically for information expression (a signal). One striking example of a group-generated cue is the time that a nectar forager just back from a foraging trip spends searching for a receiver bee to take her load of nectar. This cue provides the forager with information about her colony's need for a higher rate of nectar intake (Seeley, 1989). On average, the time that a forager must spend searching for a receiver is determined by the relative rates at which foragers arrive in the unloading area ready to give up nectar and receivers arrive in the unloading area ready to take in nectar (Seeley and Tovey, 1994). Search time is, therefore, a consequence of the activities of all the nectar foragers and all the nectar receivers in a colony. Another example of a group-generated cue is the temperature inside the hive. This is an indicator of the need for heating or cooling activities, and is a product of the thermoregulatory behaviors (heat production, ventilation, water collection, etc.) of hundreds or thousands of colony members.

\section{INDIRECT INDICATORS OF LABOR SUPPLY-DEMAND RATIOS}

The need for additional labor devoted to any given task depends ultimately on the supply of and demand for the products of this labor. Thus, a colony's need for more labor devoted to water collection depends on the relative rates of water collection and water consumption. Likewise, a colony's need for more labor devoted to comb building depends on the supply of empty comb relative to the demand for empty comb (in which to store nectar and rear brood). One might suppose, therefore, that bees inform themselves of their colony's labor needs by somehow sensing both the supply of and the demand for the products of the different forms of labor in a colony: nectar, pollen, water, propolis, clean cells, drone cells, fed brood, warmed brood, capped pupae, groomed bees, and so forth. For example, one might suppose that a nurse bee senses the need for additional labor devoted to cell cleaning by measuring the rate at which her nestmates are cleaning dirty cells (the supply) and the rate at which young bees are emerging and so producing dirty cells (the demand), and noting whether the latter exceeds the former. One might also imagine that a forager bee senses the need for additional pollen foraging by assessing the rate of pollen collection by fellow foragers and the rate of pollen consumption by the nurse bees, and noting any discrepancy between these two rates.

The approach of directly determining the supply of and demand for various labor products would provide workers with a 
precise picture of their colony's labor needs, but almost certainly it is not the usual means by which workers assess their colony's labor needs. At least to date, there is no evidence that bees make direct measurements of the supply of and demand for various goods and services in a bee hive. Probably the reason for this is that it is exceedingly difficult for a worker bee to accurately assess supply and demand as independent variables. Consider, for example, the difficulty faced by a nurse bee that is seeking to determine the need for more cell cleaning if she had to measure the overall rate of cell cleaning and the overall rate of brood emergence within her colony. Likewise, imagine the difficulty faced by a forager bee that is seeking to determine the need for more pollen foraging if she had to measure her colony's total rates of pollen collection and pollen consumption.

It now seems clear that instead of monitoring the variables of supply and demand directly, bees monitor variables that provide indirect summaries of the supply-demand ratios for the various goods and services produced in a colony. This means of control is analogous to the way a governor on a steam engine works. It detects neither the supply of work being performed by the engine (i.e. the power output of the engine) nor the demand for work by the engine (i.e. the load on the engine), but instead responds to a variable that reliably summarizes the work supply-demand situation, namely the engine speed. Any time there is a change in the supply of or the demand for work, the engine speed automatically changes. The governor responds to changes in engine speed, increasing or decreasing the flow of steam to maintain the engine speed and so keeps the work supply matched to the work demand. In the case of the bees, these indirect, summary indicators are often simply the levels of the different substrates or products of the various forms of bee labor. Thus bees may respond to the prevalence of dirty or clean cells, hungry or well-fed larvae, and cool or hot brood as indices of the need to clean cells, feed larvae and warm brood, respectively.

Sometimes, however, the indirect indicator of a particular labor need in a bee colony does not have such an obvious relationship to the changes in the supply of and demand for this labor. One example of this is the summary indicator of the need for additional labor devoted to water collection (Lindauer, 1954; Kühnholz and Seeley, 1997). Each bee engaged in water collection decides whether or not to recruit additional bees to this task not by sensing a rise in the level of water in the colony, but by sensing the difficulty of unloading water to receiver bees. How exactly this unloading difficulty is sensed remains unclear, for there are several variables of the unloading process that change simultaneously when a colony's water need changes and it remains uncertain which one(s) the bees monitor. The critical variable may be something only distantly related to the fundamental variables of water collection and water consumption, such as how long a water collector must search to find a receiver, or how many times a water collector experiences unloading rejections from receiver bees seeking nectar rather than water. A second example of the way that a summary indicator of a labor supply-demand ratio can have an obscure relationship to the underlying variables of supply and demand is the indicator of need for pollen foraging [Camazine (1993); see also the discussion in Seeley (1995)]. Although the level of the pollen stores within a hive provides an accurate index of the relative rates of pollen consumption and pollen collection, it seems that the foragers rely on another, less obvious indicator of the need for more pollen foraging. Preliminary evidence suggests that this indicator is the level of protein hunger that a for- 
ager feels, for it appears that if a colony's rate of pollen consumption exceeds its rate of pollen collection for long, the nurse bees start to give the foragers little proteinaceous food and soon these bees begin to feel hungry for protein.

The general lesson here is that although the need for labor in each task within a bee hive is fundamentally determined by discrepancy between the supply of and demand for this labor, it appears that bees assess their colony's labor needs without broad knowledge of supply-demand relationships. Instead, it appears that they rely on indirect, summary indicators of discrepancy between supply and demand. Sometimes these summary indicators are obvious - such as a buildup in the substrate or the product of a particular form of labor - but other times they are obscure.

\section{THE SHARED ENVIRONMENT AS A PATHWAY OF INFORMATION FLOW}

Information can pass between colony members in two general ways: directly from one bee to another, or indirectly through some component of the bees' shared environment (the combs and their contents, the shared food and other substances, the hive atmosphere, and the nestmates themselves). An example of the latter process is the passage of information in the process of comb building. The construction of a particular cell in a beeswax comb involves numerous bees, yet these bees never need to come together and exchange information directly. Their building actions are completely and efficiently co-ordinated by information embodied in the structure of the partially completed cell. Thus one bee might begin a cell wall by depositing a small ridge of beeswax; a second bee might continue sculpting the wall, guided by the shape of the wax ridge left by the first bee; and a third bee might decide to plane this wall to a finer thickness, responding to the construction of the previous bee. A second example of information flow through the shared environment comes from the process of nest temperature control. A colony maintains the central broodnest region of its nest at $32-36{ }^{\circ} \mathrm{C}$ in the face of ambient temperature that may range from -20 to $40^{\circ} \mathrm{C}$. The coordination of the bees involved in heating and cooling the nest occurs with little or no direct communication; each bee responds to the temperature of her immediate environment by appropriately heating it (by making intense isometric contractions of her flight muscles) or cooling it (by fanning her wings to draw cooler air into the area) (Heinrich, 1985). Hence, the temperature of the air and comb inside a hive provides an indirect means of information flow between the bees engaged heating or cooling their colony's nest.

The use of the shared environment as a pathway of information flow between bees has several important advantages over direct means of information transfer. One is that it allows easy asynchronous transfer of information between the sender and the receiver of the information. Many forms of direct communication between bees require precise synchronization of signal production and reception (since most signals are ephemeral), and may even require that sender and receiver have a certain spatial relationship at the moment of signal transmission. For example, a bee trying to obtain information from a nestmate performing a waggle dance must place her antennae within a few millimeters of the dancer at the moments she produces her waggle runs (Kirchner, 1993). Moreover, there is now evidence suggesting that successful acquisition of the dance information depends on the dance follower aligning herself directly behind the dancer at times of waggle run production (Judd, 1996). This may explain, at 
least in part, why waggle dancing bees often must produce 40 or more waggle runs to get just one nestmate successfully recruited to a food source (Seeley and Towne, 1992). Such precise temporal and spatial co-ordination between communicating individuals is not required when the information passes between them through the shared environment.

The exploitation of the shared environment as an information channel also has the important feature of providing easy passage of information from a group to an individual. This will occur whenever an individual responds to the environmental effects of the group. Good examples of this include a comb building bee responding to the results of prior comb construction by her nestmates, a thermoregulating bee responding to the nest temperature produced by her nestmates, and a foraging bee responding (though perhaps indirectly) to the level of pollen stored in the hive by her fellow foragers. And as mentioned previously, group-toindividual information flow is central to the process of colony integration.

\section{MOBILE SENDERS AND RECEIVERS OF INFORMATION}

In analyzing the sources of information used by bees in deciding how best to behave for the common good, I think it is critically important to keep in mind that bees are highly mobile creatures inside their hives. This mobility means that bees are likely to have sophisticated adaptations involving movements that help them send and receive information. Let us first consider the matter of sending information. Already it is clear that to understand fully how a particular signal contributes to the smooth functioning of a colony we must know the spatial pattern of the signal's production. This is because where a signal is produced within a hive strongly influences which colony members will receive the signal. One sees this if one compares the spatial distributions and the audiences of waggle dances and tremble dances (figure 1). Waggle dances are performed just inside the hive entrance, where they are encountered mainly by unemployed foragers that have travelled to this

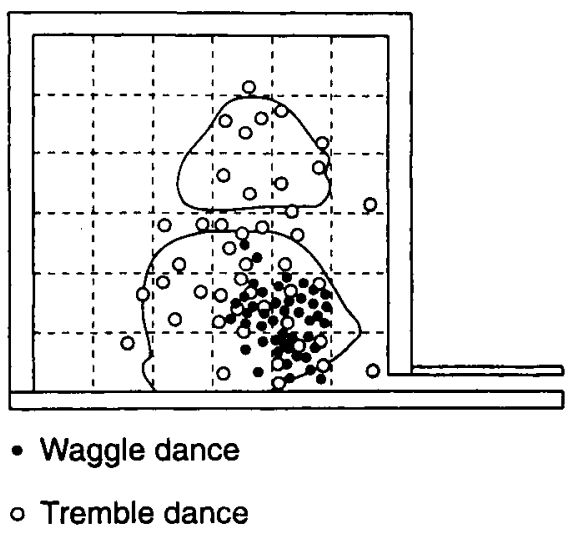

Figure 1. Spatial distributions in a two-frame observation hive of 44 waggle dances and 44 tremble dances, obtained by plotting the positions of dancers observed in scan samples made at 2-min intervals over $60 \mathrm{~min}$. Outlined areas in the hive denote regions containing brood. After Seeley (1992). 
location specifically to obtain information about foraging opportunities (von Frisch, 1967; Seeley, 1995). Tremble dances, however, are performed throughout the hive and so are encountered by all types of bees, including many inactive bees. Consequently a broad range of bees is alerted to the colony's need for additional receiver bees, which is adaptive since during a strong nectar flow a colony may need to devote up to half of it's members to the task of processing nectar (Seeley et al., 1996).

Another illustration of the idea that the movement patterns of worker bees can be adaptations for improved sending of information is what one sees with messenger bees. These bees pick up the queen's pheromone and then travel about the broodnest actively dispersing this chemical signal of the queen's presence (Velthuis, 1972; Seeley, 1979; Ferguson and Free, 1980). This pattern of messenger bee movement can be viewed as a means of achieving rapid telecommunications from one sender (the queen) to many receivers (the workers). Likewise, it seems clear that the scrambling of buzz-runners over the combs at the moment of swarm departure from the hive is an adaptation to send quickly and broadly the message 'let's go!' (Martin, 1963). I suspect that it is generally true that bees produce their signals with particular spatial distributions inside the hive, and that this enhances the effectiveness of the signals, but this remains a largely unexplored aspect of honey bee communication.

The mobility of worker bees probably also underlies adaptations for the acquisition of information. In principle, the capacity for independent travel about the hive enables the members of a colony to personally gather information over a wide area inside the hive. Lindauer (1952) aptly named this process 'patrolling'. It remains unclear, however, exactly how important patrolling is to bees. Lindauer documented that the young and middle age bees in a colony, the ones that work primarily inside the hive - cleaning cells, tending brood, storing food, and so forth - do travel about a good deal, so it seems likely that they obtain and integrate information from various locations within the hive, but we still know very little about the phenomenon of patrolling. How wide-ranging is a patrolling bee's reconnaissance? What is the temporal pattern of patrolling? What signals and cues are registered during patrolling? Are patrolling bees selective about the information that they register, as a function of the tasks currently being performed? These are but a few of the questions that must be answered before we will understand what information a patrolling bee is actually acquiring. And given that information collection is a critical component of a worker bee's decision-making process as she chooses what to do and how to do it, we must conclude that our lack of knowledge about patrolling remains a major obstacle to our solving the mystery of colony integration.

\section{ACKNOWLEDGMENTS}

The research that inspired the thoughts presented here was supported by National Science Foundation grants BNS-8606778, BNS8916006, IBN92-21150 and IBN96-30159, for which I am most grateful.

Résumé - Réflexions sur l'information et l'intégration dans les colonies d'abeilles, Apis mellifera L. Résoudre le mystère de l'intégration de la colonie chez les abeilles mellifères implique de comprendre comment une ouvrière acquiert l'information nécessaire pour décider correctement, instant après instant, quelle tâche accomplir et comment. À ce sujet je fais part de quelques réflexions. Premièrement, lorsqu'on étudie le flux d'informations dans les colonies, il faut 
mettre l'accent sur l'analyse des signaux, c'est-à-dire des variables porteuses d'information qui se sont développées spécifiquement pour transmettre 1'information. Nous ne devons pourtant oublier que lorsqu'une abeille traite l'information exprimée par un signal, elle intègre souvent cette information dans tout un contexte informationnel. C'est pourquoi nous devons aussi analyser l'information contextuelle utilisée par les abeilles en association avec chaque signal. Deuxièmement, une grande partie de l'information qui permet à l'abeille de prendre des décisions provient d'indications, c'est-àdire de variables porteuse d'information qui ne se sont pas développées spécifiquement pour transmettre l'information, mais qui l'ont fait incidemment. La majeure partie des sources d'information de la ruche sera probablement des indications plutôt que des signaux. Si l'on compare les signaux et les indications dans la colonie d'abeilles (tableaux $I$ et $I I$ ), on s'aperçoit que ces dernières surpassent largement les premiers. Troisièmement, le besoin d'une colonie d'abeilles en un matériel ou un service donnés dépend en dernier ressort du rapport entre.son offre et sa demande. Pourtant, plutôt que de surveiller les variables d'offre et de demande, les abeilles surveillent habituellement d'autres variables qui résument les rapports d'offre/demande, car souvent ces indicateurs condensés sont à la fois d'une perception facile et des sources d'information très fiables. Quatrièmement, une large part du flux d'information entre les membres d'une colonie parvient indirectement par l'intermédiaire d'éléments de l'environnement commun plutôt que directement d'une abeille à l'autre. L'utilisation de l'environnement commun comme canal d'information permet une communication asynchrone facile et un passage aisé de l'information du groupe à l'individu. Et cinquièmement, étant donné la mobilité des abeilles à l'intérieur de la ruche, celles-ci ont vraisemblablement développé des adaptations sophistiquées qui impliquent le mouvement et les aident à envoyer et recevoir l'information. «Patrouiller », courir çà et là dans la ruche pour collecter l'information, est peut-être la plus importantes de ces adaptations, mais nous savons à ce jour peu de choses concernant ce moyen visiblement crucial de collecte de l'information. (C) Inra/DIB/ AGIB/Elsevier, Paris

\section{Apis mellifera / communication / infor- mation / comportement social / inté- gration colonie}

\section{Zusammenfassung - Überlegungen über Information und Integration bei} Honigbienenvölkern. Ein Teil der Lösung des Rätsels der Integration der Honigbienenvölker liegt in dem Verständnis, wie die einzelne Arbeiterin die adaequate Information aufnimmt, anhand derer sie richtig und von Augenblick zu Augenblick entscheidet, welche Aufgabe sie verrichtet und wie sie dies tut. Hier möchte ich einige Gedanken mitteilen, die uns das Verständnis der Informationsaufnahme durch die Bienen innerhalb des Volkes erleichtern sollen. Zunächst halte ich es für das Studium des Informationsflusses in den Bienenvölkern für angemessen, eine besondere Betonung auf die Analyse von Signalen im Sinne von spezifisch zu diesem Zweck evolvierten informationstragenden Variablen zu legen. Allerdings müssen wir uns in diesem Zusammenhang klar machen, daß eine Biene, sobald sie die in einem Signal enthaltene Information verarbeitet, diese oftmals mit einer grossen Menge kontextbezogener Information verrechnet. Wir müssen daher ebenso die Information aus dem Kontext berücksichtigen, die von den Arbeiterinnen in Verbindung mit jedwedem Signal benutzt wird. Zweitens entstammt sehr viel der Information, die die Arbeiterinnen zu einem bestimmten Verhalten veranlaßt, aus Hinweisen ('cues'), d.h. aus 
informationstragenden Variablen, die sich nicht spezifisch zur Übertragung von Information entwickelt haben, sondern die dies nur beiläufig tun. Höchstwahrscheinlich wird sich herausstellen, daß der überwiegende Teil der Informationsquellen einer Innendienst-Bienenarbeiterin eher aus Hinweisen als aus Signalen besteht. Ein Vergleich der bekannten Signale und der Hinweise in Honigbienenvölkern (Tabelle $I$ und $I$ ) zeigt auf, daß die letzteren bei weitem häufiger sind als die ersteren. Zum Dritten hängt der Bedarf an einem bestimmten Material oder Dienst in einem Honigbienenvolk letztendlich von dem Verhältnis zwischen dessen Bereitstellung und der Nachfrage ab. Allerdings, anstelle Bereitstellungs - und Nachfragevariablen direkt zu messen, erfassen Bienen zumeist weitere Variablen, die das Verhältnis zwischen Bereitstellung und Nachfrage zusammenfassen. Der Grund ist, daß solche zusammenfassenden Indikatoren oft einerseits leicht wahrzunehmen sind, andererseits aber auch hochzuverlässige Informationsquellen darstellen. Viertens wird ein großer Teil des Informationsflusses zwischen den Koloniemitgliedern eher indirekt über Komponenten aus der gemeinsamen Umwelt vermittelt als direkt von einer Biene zur anderen. Die Nutzung der gemeinsamen Umgebung als Informationskanal ist eine leichte Möglichkeit zur asynchroner Kommunikation und zur Übermittlung von Information von der Gruppe zum Individuum. Und fünftens besteht in Anbetracht der Mobilität der Bienen eine hohe Wahrscheinlichkeit für die Entstehung höchstentwickelter Anpassungen, die sowohl für das Aussenden als auch das Empfangen von Information eine Bewegungskomponente enthalten. Die wichtigste dieser Anpassungen ist möglicherweise das 'Patrouilliern', das Umherlaufen von Arbeiterinnen zum Informationsgewinn, allerdings wissen wir bislang nur sehr wenig über dieses offensichtlich wesentliche Mittel für das Ansammeln von Information. (C) Inra/DIB/AGIB/Elsevier, Paris

\section{Apis mellifera / Kommunikation / Honigbienen / Information / Sozialver- halten}

\section{REFERENCES}

Breed MD (1985) How honeybees recognize their nestmates: a re-evaluation from new evidence. Bee World 66, 113-118

Camazine $S$ (1993) The regulation of pollen foraging by honey bees: how foragers assess the colony's need for pollen. Behav Ecol Sociobiol 32, 265-272

Darchen R ( 1968) Le travail de la cire et la construction dans la ruche. In: Traité de Biologie de l'Abeille. Vol. 2 (R Chauvin, ed), Masson, Paris, 241-331

Ferguson AW, Free JB ( 1980 ) Queen pheromone transfer within honeybee colonies. Physiol Entomol 5, 359-366

Free JB (1967) The production of drone comb by honeybee colonies. J Apic Res 6, 29-36

Frisch K von (1967). The Dance Language and Orientation of Bees. Harvard Univ Press, Cambridge

Heinrich B (1985) The social physiology of temperature regulation in honeybees. In: Experimental Behavioral Ecology and Sociobiology (B Hölldobler, M Lindawer, eds), Sinauer, Sunderland, 393-406

Heran H (1952) Untersuchungen über den Temperatursinn der Honigbiene (Apis mellifica) unter besonderer Berücksichtigung der Wahrnehmung strahlender Wärme. Z vergl Physiol 34, 179-206

Hess C von (1916) Messende Untersuchung des Lichtsinnes der Biene. Arch ges Physiol 163 , 289-320

Judd TM (1995) The waggle dance of the honey bee: which bees following a dancer successfully acquire the information? J Insect Behav 8 , 343-354

Kirchner W (1993) Acoustical communication in honeybees. Apidologie 24, 297-307

Koeniger N (1970) Factors determining the laying of drone and worker eggs by the queen honeybee. Bee World 51, 166-169

Koeniger N, Veith HJ (1983) Glyceryl-1,2-dioletate-3-palmitate as a brood pheromone of the honey bee (Apis mellifera L.). Experientia 39. 1051-1057

Kühnholz S, Seeley TD (1997) The control of water collection in honeybee colonies. Behav Ecol Sociobiol 41, 407-422 
Lensky Y, Slabezki Y (1981) The inhibiting effect of the queen bee (Apis mellifera L.) foot-print pheromone on the construction of swarming queen cups. I Insect Physiol 27, 313-323

Lindauer M (1952) Ein Beitrag zur Frage der Arbeitsteilung im Bienenstaat. $Z$ vergl Physiol 34, 299-345

Lindauer M (1954) Temperaturregulierung und Wasserhaushalt im Bienenstaat. Z vergl Physiol $36,391-432$

Lloyd JE (1983) Bioluminescence and communication in insects. Annu Rev Entomol 28, 131-160

Martin H, Lindauer M (1966) Sinnesphysiologische Leistungen beim Wabenbau der Honigbiene. $Z$ vergl Physiol 53, 372-404

Martin P (1963) Die Steuerung der Volksteilung beim Schwärmen der Bienen. Zugleich ein Beitrag zum Problem der Wanderschwärme. Insectes Soc 10, 13-42

Milum VG (1947) Grooming dance and associated activities of the honeybee colony. Illinois Acad Sci Trans 40, 194-196

Park OW (1925) The storing and ripening of honey by honeybees. J Econ Entomol 18, 405-410

Parker RL (1926) The collection and utilization of pollen by the honeybee. Mem Cornell Agric Exp Sta 98, 1-55

Pratt SC Condition-depend timing of comb construction by honeybee colonies: experimental tests of an optimization model (submitted)

Pratt SC, Kühnholz S, Seeley TD, Weidenmüller A (1996) Worker piping associated with foraging in undisturbed queenright colonies of honey bees. Apidologie 27, 13-20

Ratnieks FLW (1995) Evidence for a queen-produced egg-marking pheromone and its use in worker policing in the honey bee. J Apic Res 34 , 31-37

Renner M, Vierling G (1977) Die Rolle des Taschendruisenpheromons beim Hochzeitsflug der Bienenkönigin. Behav Ecol Sociobiol 2, 329-338

Rinderer TE (1982) Volatiles from empty comb increase hoarding by the honey bee. Anim Behav 29, 1275-1276

Sandeman DC, Tautz J, Lindauer M (1996) Transmission of vibration across honeycombs and its detection by bee leg receptors. J Exp Biol 199 , 2585-2594

Schneider SS, Stamps JA, Gary NE (1986) The vibration dance of the honeybee. I. Communi- cation regulating foraging on two time scales. Anim Behav 34, 377-385

Seeley TD (1974) Atmospheric carbon dioxide regulation in honey-bee (Apis mellifera) colonies. $J$ Insect Physiol 20, 2301-2305

Seeley TD (1979) Queen substance dispersal by messenger workers in honeybee colonies. Behav Ecol Sociobiol 5, 391-415

Seeley TD (1989) Social foraging in honey bees: how nectar foragers assess their colony's nutritional status. Behav Ecol Sociobiol 24, 181-199

Seeley TD (1992) The tremble dance of the honey bee: message and meanings. Behav Ecol Sociobiol 31, 375-383

Seeley TD (1995) The Wisdom of the Hive. Harvard Univ Press, Cambridge

Seeley TD, Morse RA (1976) The nest of the honey bee (Apis mellifera L.). Insectes Soc 23, 495-512

Seeley TD, Morse RA (1978) Nest site selection by the honey bee. Insectes Soc 25, 323-337

Seeley TD, Tovey CA (1994) Why search time to find a food-storer bee accurately indicates the relatives rates of nectar collection and nectar processing in honey bee colonics. Anim Behav 47 , 311-316

Seeley TD, Towne WF (1992) Tactics of dance choice in honey bees: do foragers compare dances? Behav Ecol Sociobiol 30, 59-69

Seeley TD, Kühnholz S, Weidenmüller A (1996) The honey bee's tremble dance stimulates additional bees to function as nectar receivers. Behav Ecol Sociobiol 39, 419-427

Simpson J (1973) Influence of hive-space restriction on the tendency of honeyhee colonies to rear queens. J Apic Res 12, 183-186

Simpson J, Cherry SM (1969) Queen confinement, queen piping and swarming in Apis mellifera colonies. Anim Behav 17, 271-278

Velthuis HHW (1972) Observations on the transmission of queen substances in the honey bee colony by the attendants of the queen. Behaviour 41, 105-129

Visscher PK (1983) The honey bee way of death: necrophoric behaviour in Apis mellifera colonies. Anim Behav' 31, 1070-1076

Winston ML (1987) The Biology of the Honey Bee. Harvard Univ Press, Cambridge

Winston ML, Slessor KN (1992) The essence of royalty: honey bee queen pheromone. Am Sci 80, 374-385 